\title{
A Review: Scanning Electrochemical Microscopy (SECM) for Visualizing the Real-Time Local Catalytic Activity
}

\author{
Anant Preet ${ }^{1,2,3}$ and Tzu-En Lin $1, * \mathbb{D}$ \\ 1 Institute of Biomedical Engineering, College of Electrical and Computer Engineering, \\ National Yang Ming Chiao Tung University, Hsinchu 30010, Taiwan \\ 2 Department of Chemistry (Chemical Biology Division), College of Science, National Taiwan University, \\ Taipei 10617, Taiwan; d09223205@ntu.edu.tw \\ 3 Chemical Biology and Molecular Biophysics Program, Taiwan International Graduate Program, \\ Institute of Biological Chemistry, Academia Sinica, Nankang, Taipei 11529, Taiwan \\ * Correspondence: telin@nctu.edu.tw
}

Citation: Preet, A.; Lin, T.-E. A Review: Scanning Electrochemical Microscopy (SECM) for Visualizing the Real-Time Local Catalytic Activity Catalysts 2021, 11, 594. https:// doi.org/10.3390/catal11050594

Academic Editor: Eric M. Gaigneaux

Received: 29 March 2021

Accepted: 1 May 2021

Published: 4 May 2021

Publisher's Note: MDPI stays neutral with regard to jurisdictional claims in published maps and institutional affiliations.

Copyright: (c) 2021 by the authors. Licensee MDPI, Basel, Switzerland. This article is an open access article distributed under the terms and conditions of the Creative Commons Attribution (CC BY) license (https:// creativecommons.org/licenses/by/ $4.0 /)$.

\begin{abstract}
Scanning electrochemical microscopy (SECM) is a powerful scanning probe technique for measuring the in situ electrochemical reactions occurring at various sample interfaces, such as the liquid-liquid, solid-liquid, and liquid-gas. The tip/probe of SECM is usually an ultramicroelectrode (UME) or a nanoelectrode that can move towards or over the sample of interest controlled by a precise motor positioning system. Remarkably, electrocatalysts play a crucial role in addressing the surge in global energy consumption by providing sustainable alternative energy sources. Therefore, the precise measurement of catalytic reactions offers profound insights for designing novel catalysts as well as for enhancing their performance. SECM proves to be an excellent tool for characterization and screening catalysts as the probe can rapidly scan along one direction over the sample array containing a large number of different compositions. These features make SECM more appealing than other conventional methodologies for assessing bulk solutions. SECM can be employed for investigating numerous catalytic reactions including the oxygen reduction reaction (ORR), oxygen evolution reaction (OER), hydrogen evolution reaction (HER), water oxidation, glucose oxidation reaction (GOR), and $\mathrm{CO}_{2}$ reduction reaction $\left(\mathrm{CO}_{2} \mathrm{RR}\right)$ with high spatial resolution. Moreover, for improving the catalyst design, several SECM modes can be applied based on the catalytic reactions under evaluation. This review aims to present a brief overview of the recent applications of electrocatalysts and their kinetics as well as catalytic sites in electrochemical reactions, such as oxygen reduction, water oxidation, and methanol oxidation.
\end{abstract}

Keywords: scanning electrochemical microscopy; ultramicroelectrode; catalyst; electrocatalysis

\section{Introduction}

Advances in electrochemical technologies have played a crucial role in gaining deeper insights into the electrochemical reactions occurring at solid-liquid, liquid-liquid as well as liquid-gas interfaces [1-3]. Electrochemical techniques have gained worldwide interest over the recent years as they offer an efficient platform to study the renewable and sustainable energy generation arising from various electrocatalytic chemical reactions, such as photoelectrochemical (PEC) splitting of water, the electrochemical production of $\mathrm{H}_{2} \mathrm{O}_{2}$, the electroreduction of $\mathrm{CO}_{2}$, glucose-based biofuel cells (GFCs) for assessing electrocatalytic glucose oxidation, and water splitting reactions [4-10].

Scanning probe microscopy (SPM) techniques, especially scanning electrochemical microscopy (SECM), can be utilized for the screening of a large number of electrocatalysts and instantaneous in-situ product analysis [11,12]. SECM comprises of an ultramicroelectrode (UME) or a nanoelectrode (NE) acting as the probe (depending on the sample sizes) that enables the efficient mapping of localized electrochemical activity over various homogeneous and heterogeneous surfaces $[13,14]$. The catalytic reactions may occur heterogeneously on 
the sample surfaces, and thus SECM can be used to understand the reaction sites, nature of spatial variations, and reaction dynamics of the catalytic systems. Table 1 summarizes the recent advances of SECM for evaluating catalysts. For instance, SECM can measure a variety of localized catalytic redox reactions, including oxygen reduction reaction (ORR) [15-17], oxygen evolution reaction (OER) [18,19], hydrogen evolution reaction (HER) [15,20-22], water oxidation [23], glucose oxidation reaction (GOR) [24,25], and $\mathrm{CO}_{2}$ reduction reaction $\left(\mathrm{CO}_{2} \mathrm{RR}\right)[26,27]$. Furthermore, SECM can be employed for the determination of short-lived intermediates (such as electrochemically generated radicals) [28].

Table 1. Recent advances in the applications of SECM for assessing catalysts.

\begin{tabular}{|c|c|c|c|c|c|}
\hline Instrumentation & Material of the Probe & Mode & Catalysts & Catalytic Reaction & References \\
\hline SECM & $\mathrm{Pt}$ & $\mathrm{RC}$ & $\begin{array}{l}\text { PdW nanoparticles } \\
\text { supported on } \\
\text { nitrogen and sulfur } \\
\text { co-doped } \\
\text { graphene (NSG) }\end{array}$ & ORR & [29] \\
\hline SECM & $\mathrm{Au}$ & SG/TC & $\begin{array}{c}\text { Nanowires of } \\
\text { silver chloride and } \\
\text { bromide } \\
\text { (AgClNWs and } \\
\text { AgBrNWs) }\end{array}$ & ORR & [30] \\
\hline SECM & $\mathrm{Pt}$ & $\mathrm{RC}$ & $\begin{array}{l}\text { Octahedral cobalt } \\
\text { sulfide }\left(\mathrm{CoS}_{2}\right)\end{array}$ & ORR & [31] \\
\hline SECM & $\mathrm{Pt}$ & $\mathrm{RC}$ & $\begin{array}{l}\text { Manganese } \\
\text { tungstate } \\
\left(\mathrm{MnWO}_{4}\right)\end{array}$ & ORR & [32] \\
\hline AFM-SECM & $\mathrm{Pt}$ & $\begin{array}{c}\text { SG/TC; } \\
\text { Direct mode }\end{array}$ & $\begin{array}{c}\mathrm{Fe}-\mathrm{N} \text { doped planar } \\
\text { graphite }\end{array}$ & $\begin{array}{l}\text { ORR; } \mathrm{H}_{2} \mathrm{O}_{2} \\
\text { production }\end{array}$ & [16] \\
\hline SECM & $\mathrm{Pt}$ & SG/TC & $\begin{array}{c}\text { nickel and } \\
\text { cobalt-based } \\
\text { oxides } \\
\left(\mathrm{NiO}, \mathrm{Co}_{3} \mathrm{O}_{4} \text { and }\right. \\
\left.\mathrm{Ni}_{\mathrm{x}} \mathrm{Co}_{3-\mathrm{x}} \mathrm{O}_{4}\right)\end{array}$ & $\begin{array}{c}\mathrm{HO}_{2}^{-} \text {production } \\
\text { in ORR }\end{array}$ & [9] \\
\hline SECM & $\mathrm{Au}$ & $\mathrm{FB}$ & $\begin{array}{c}\text { Copper } \\
\text { nanostructures } \\
(\text { CuNSs })\end{array}$ & $\begin{array}{l}\mathrm{ORR} \text { and } \mathrm{CO}_{2} \\
\text { reduction }\end{array}$ & [33] \\
\hline SECM & $\mathrm{Cu}$ and $\mathrm{Fe}$ & $\mathrm{TG} / \mathrm{SC}$ & Copper & ORR; HER; $\mathrm{CO}_{2} \mathrm{RR}$ & [34] \\
\hline SECM & $\mathrm{Pt}$ & $\begin{array}{l}\text { SG/TC; } \\
\text { RC }\end{array}$ & $\begin{array}{l}\text { Nitrogen-bearing } \\
\text { carbon spheres } \\
\text { (NCSs) }\end{array}$ & $\begin{array}{l}\text { ORR; } \mathrm{H}_{2} \mathrm{O}_{2} \\
\text { production }\end{array}$ & [35] \\
\hline SECM & $\mathrm{Pt}$ & $\mathrm{RC}$ & $\begin{array}{c}\text { Nanostructured } \\
\text { hybrids based on } \\
\mathrm{MoSe}_{2} \text { on reduced } \\
\text { graphene } \\
\text { oxide (rGO) } \\
\text { nanosheets }\end{array}$ & ORR & [36] \\
\hline SECM & $\mathrm{Pt}$ & $\begin{array}{l}\mathrm{SG} / \mathrm{TC} ; \\
\mathrm{TG} / \mathrm{SC} ; \\
\mathrm{RC}\end{array}$ & $\begin{array}{c}\text { Multiwalled } \\
\text { Carbon nanotubes } \\
\text { (MWCNTs) with } \\
\text { cobalt(IX) } \\
\text { protoporphyrin } \\
\text { (MWCNTs/CoP) }\end{array}$ & $\begin{array}{l}\text { ORR; } \mathrm{H}_{2} \mathrm{O}_{2} \\
\text { production }\end{array}$ & [37] \\
\hline
\end{tabular}


Table 1. Cont.

\begin{tabular}{|c|c|c|c|c|c|}
\hline Instrumentation & Material of the Probe & Mode & Catalysts & Catalytic Reaction & References \\
\hline SECM & $\mathrm{Pt}$ & $\mathrm{RC}$ & $\begin{array}{c}\mathrm{ZnCo}_{2} \mathrm{O}_{4} \text { on } \\
\text { carbon nanotubes } \\
\left(\mathrm{ZnCo}_{2} \mathrm{O}_{4} / \mathrm{CNTs}\right) \\
\text { and } \mathrm{Pt} / \mathrm{C}\end{array}$ & ORR & [38] \\
\hline AFM-SECM & Au-c-Pt tip & SG/TC & $\begin{array}{c}\text { Platinum } \\
\text { nanoparticles } \\
\text { (Pt NPs) }\end{array}$ & $\begin{array}{l}\text { ORR; } \mathrm{H}_{2} \mathrm{O}_{2} \\
\text { production }\end{array}$ & [39] \\
\hline SECM-SICM & $\begin{array}{l}\text { Pt coated pyrolytic } \\
\text { carbon }\end{array}$ & $\begin{array}{l}\text { SG/TC; } \\
\text { RC }\end{array}$ & $\begin{array}{l}\text { Gold nanoparticles } \\
\text { (Au NPs) }\end{array}$ & $\begin{array}{l}\text { ORR; } \mathrm{H}_{2} \mathrm{O}_{2} \\
\text { generation }\end{array}$ & {$[40]$} \\
\hline Raman-SECM & Glassy carbon & SG/TC & $\begin{array}{l}\text { Lithium } \\
\text { intercalated nickel } \\
\text { phosphorus } \\
\text { trisulfide }\left(\mathrm{NiPS}_{3}\right)\end{array}$ & OER & [41] \\
\hline SI-SECM & $\mathrm{Au}$ & FB & $\mathrm{CoP}_{\mathrm{i}}$ nanosheets & $\begin{array}{l}\text { Water oxidation, } \\
\text { OER }\end{array}$ & [23] \\
\hline Raman-SECM & $\mathrm{Pt}$ & SG/TC & $\begin{array}{l}\mathrm{Ni} / \mathrm{Fe} \text { and } \mathrm{Ni} \text { thin } \\
\text { films }\end{array}$ & OER & [42] \\
\hline SECM & $\mathrm{Pt}$ & SG/TC & $\begin{array}{l}\text { reduced graphene } \\
\text { oxide supported } \\
\mathrm{ZnCo}_{2} \mathrm{O}_{4} \\
\text { microsphere } \\
\left(\mathrm{rGO}-\mathrm{ZnCo}_{2} \mathrm{O}_{4}\right)\end{array}$ & ORR; OER & {$[43]$} \\
\hline SECM & $\mathrm{Pt}$ & SG/TC & $\begin{array}{c}\text { Cobalt-based } \\
\text { metalloids } \\
\left(\mathrm{Co}_{\times} \mathrm{B} \text { and } \mathrm{Co}_{x} \mathrm{P}\right) \\
\text { composites }\end{array}$ & ORR, OER; & {$[44]$} \\
\hline SECM & $\mathrm{Pt}$ & SG/TC & $\begin{array}{l}\text { Mesoporous } \\
\text { single-atom-doped } \\
\text { graphene-carbon } \\
\text { nanotube hybrid }\end{array}$ & ORR; OER & [45] \\
\hline SECM & $\mathrm{Pt}$ & SG/TC; FB & $\begin{array}{c}\text { MXenes } \\
\text { (2D early transition } \\
\text { metal carbide) }\end{array}$ & HER & [21] \\
\hline SECM & $\mathrm{Pt}$ & SG/TC & $\begin{array}{c}\text { Iron sulfide }\left(\mathrm{FeS}_{2}\right) \\
\text { nanostructures } \\
(1 \mathrm{D}, \text { wires and } 2 \mathrm{D}, \\
\text { discs })\end{array}$ & HER & [46] \\
\hline SECM & $\mathrm{Pt}$ & SG/TC & $\begin{array}{l}\text { Metal-organic } \\
\text { frameworks } \\
\left(\mathrm{CoS}_{\mathrm{x}} \mathrm{MOFs}\right)\end{array}$ & HER & [15] \\
\hline SECM & $\mathrm{Pt}$ & SG/TC & $\begin{array}{l}\text { Sulfur vacancies } \\
\text { on Molybdenum } \\
\text { disulfide } \\
\left(\mathrm{SV}-\mathrm{MoS}_{2}\right)\end{array}$ & HER & [47] \\
\hline SECM & $\mathrm{Pt}$ & $\begin{array}{c}\text { FB; } \\
\text { SG/TC }\end{array}$ & $\begin{array}{c}\text { Mixed-phase } \mathrm{MoS}_{2} \\
\text { nanosheets }\end{array}$ & HER & [48] \\
\hline SECM & $\mathrm{Pt}$ & SG/TC & $\begin{array}{c}\mathrm{Ni} \text { and } \\
\mathrm{Ni} / \alpha-\mathrm{Ni}(\mathrm{OH})_{2} \\
\text { heterostructures }\end{array}$ & HER, OER & [49] \\
\hline
\end{tabular}


Table 1. Cont.

\begin{tabular}{|c|c|c|c|c|c|}
\hline Instrumentation & Material of the Probe & Mode & Catalysts & Catalytic Reaction & References \\
\hline SECM & $\mathrm{Pt}$ & SG/TC & $\begin{array}{l}\text { Decamethylruthenocen } \\
\text { (DMRc) in 1,2- } \\
\text { dichloroethane/water } \\
\text { (DCE I W) biphasic } \\
\text { system }\end{array}$ & ne & {$[50]$} \\
\hline SECM & Carbon; Pt & $\begin{array}{c}\text { FB; } \\
\text { SG/TC }\end{array}$ & $\begin{array}{c}\text { Silver } \\
\text { nanoparticles (Ag } \\
\text { NPs) and silver } \\
\text { nanoclusters (Ag } \\
\text { NCs) on multi-wall } \\
\text { carbon nanotubes } \\
\text { (MWCNT) }\end{array}$ & $\begin{array}{l}\text { Bicarbonate } \\
\text { reduction }\end{array}$ & [51] \\
\hline SECM & $\mathrm{Hg} / \mathrm{Pt}$ & TG/SC & Au metal surface & $\begin{array}{l}\text { Intermediate of } \\
\mathrm{CO}_{2} \text { reduction }\end{array}$ & [52] \\
\hline
\end{tabular}

Depending on the type of electrocatalysis and catalyst used, SECM can operate via various working modes, such as substrate-generation/tip-collection (SG/TC) mode, tip-generation/sample-collection (TG/SC) mode, feedback (FB) mode, redox competition (RC) mode, and direct mode. SECM acts as an ideal tool for assessing the catalytic/electrocatalytic reactions as well as for determining the catalytic efficiency of electrocatalysts based on numerous features, including the electron transfer mechanism, oxidation potential, current density, surface morphology, electronic band structures, porosity, tunability, and availability of active edge sites [11]. High-precision and real-time monitoring of localized catalytic electrochemical reactions can provide a remedy to numerous biotechnological problems such as corrosion of polymers and carbon-based materials, the decay of biofuel cells, etc. [11,12]. The understanding of these chemical reactions may accelerate the development of new technologies and guide the scientists to conduct more precise research $[53,54]$.

In this review, we provide deeper insights into employing SECM to tackle conventional problems related to electrocatalysis. Herein, we summarize the applications of SECM for determining the local and real-time measurements of catalytic redox reactions. We emphasize how SECM can be a very promising tool to improve the design of electrocatalysts and hence, for exhibiting crucial information about the reaction mechanisms that can ultimately combat various conventional problems faced in biotechnological applications.

\section{Introduction to SECM}

SECM belongs to the scanning probe microscopy family that consists of a probe that shifts in the vicinity of a substrate interface, and thereby, offering a map of the localized information and/or reactivity based on the sample-probe interaction using different operating modes $[28,55,56]$. SECM has been used in many fields such as electrochemistry, materials science, catalysis, and biochemistry [57-60]. Also, SECM can be combined with various other SPM methodologies such as atomic force microscopy (AFM), scanning ion-conductance microscopy (SICM), scanning electrochemical cell microscopy, etc., and hence, it becomes a very powerful tool for measuring multiple types of signals simultaneously $[61,62]$.

The most important part of the SECM set-up is the probe that is usually an UME or a NE on which the electrochemical redox process occurs. The SECM probe is connected to a precise motor positioning system so that the probe can efficiently move in the $\mathrm{x}, \mathrm{y}$, and z-directions. Figure 1 demonstrates the basic instrumentation of SECM. Generally, a three-electrode system, comprising of a working electrode (probe), reference electrode, and counter electrode, is used for SECM measurements. The potential applied to the probe is controlled by a potentiostat. The sample is immersed in an electrolyte solution and fixed 
on a substrate. The probe can smoothly move along the z-direction, making an approach curve that provides the kinetic and reactivity information. In the imaging mode, the UME is placed in a certain z-position close to the sample, whereas the probe scans across the $\mathrm{x}$ and y-direction. Therefore, a map of Faradaic current distribution can be acquired.

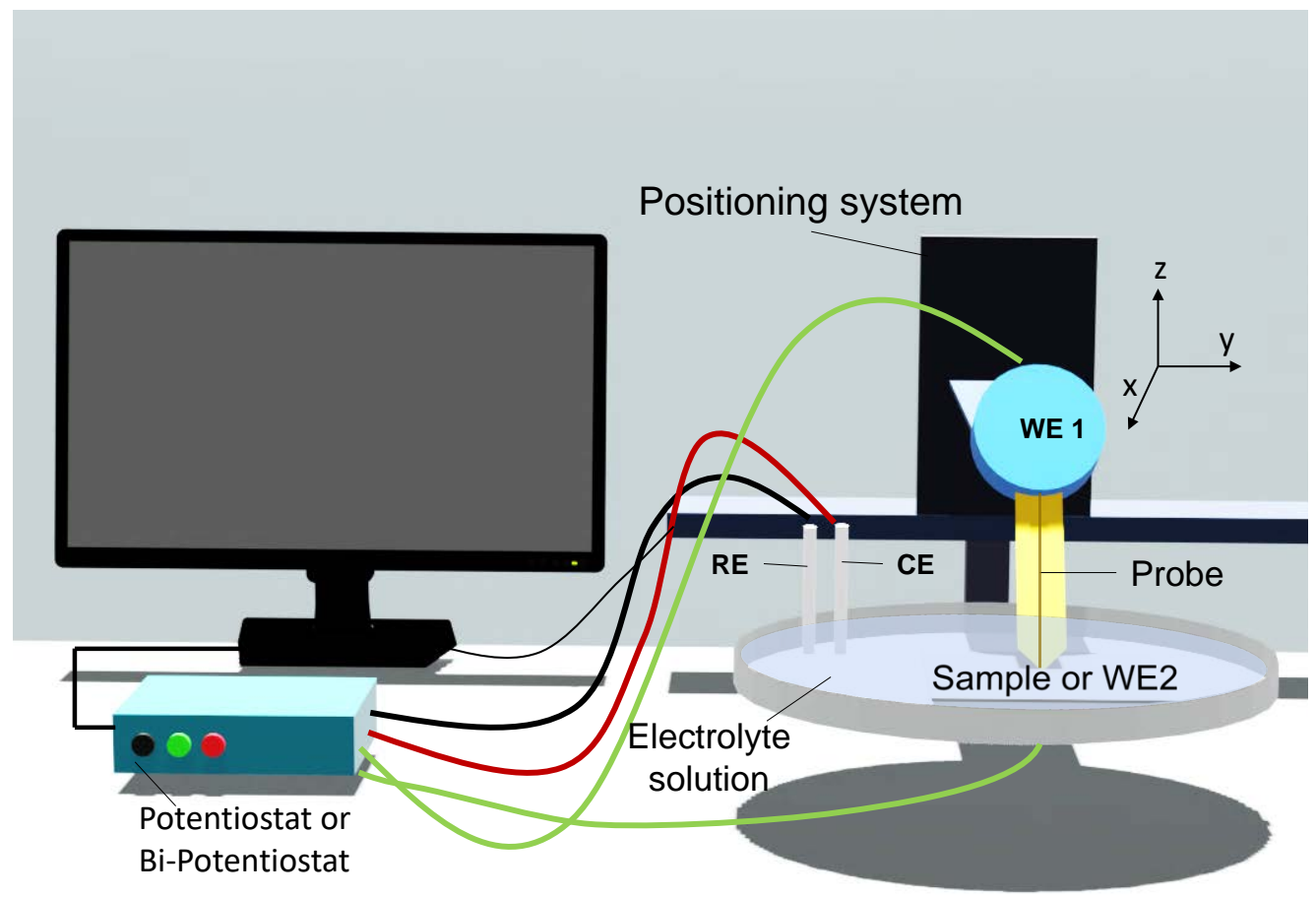

Figure 1. Illustration of the instrumentation of SECM with a soft probe.

SECM is a diffusion-based technique, in which the hemispherical diffusion occurs around the UME as shown in Figure 2. As compared to conventional microelectrodes, where the diffusion of species occurs perpendicularly, the mass transfer in hemispherical diffusion is faster so that the diffusion-limited currents can be measured in the bulk solution. Therefore, smaller dimensions of the electrode offer a superior sensitivity in electrochemical measurements owing to their low ohmic drop, low capacitive current, and fast mass transport. If the UME reaches the steady-state in bulk solution, the current can be expressed via the following equation derived from Fick's law: [63]

$$
i_{\mathrm{T}, \infty}=4 n F D C_{R}^{*}{ }^{*}{ }_{\mathrm{T}}
$$

where $n$ is the number of electrons transferred per molecule or ion, $F$ is the Faraday constant, $D$ is the diffusion coefficient, $C_{R}{ }^{*}$ is the concentration of a species " $R$ " in the bulk solution and $r_{\mathrm{T}}$ is the radius of the disk-shaped UME.

Recently, Prof. Tzu-En Lin has dedicated her work to develop a "soft UME probe" for efficient SECM measurements [57,60,64,65]. The soft UME can even scan the samples having curvature or rough surfaces, such as apple peels and cancer tissues, in contact mode. As Figure 1 shows, the UME is made of flexible materials so that the probe can accurately scan in contact mode, unlike the traditional UME, which is made of a rigid glass that makes it moderately difficult to manipulate, as the current signals often get interfered by the change of probe-sample distance. Thus, the Soft-Probe-SECM is an excellent alternative to overcome the challenges faced with the traditional SECM methodologies.

\section{SECM Operation Modes}

The utilization of various operation modes is contingent based on the purpose of the SECM experiments. Figure 2 summarizes several common operation modes reported in an analysis of catalysts, including the feedback mode (FB), tip generation/substrate 
collection (TG/SC) mode as well as substrate generation/tip collection (SG/TC) mode, and redox competition mode (RC). Among these different modes, the feedback mode and the generation/collection mode are the most widely used for SECM imaging. A reduced species " $R$ " existing as a free redox mediator in the bulk solution, which gets oxidized to the oxidized species " $\mathrm{O}$ " by a polarized UME, can be studied via Equation (2):

$$
\mathrm{R} \rightarrow \mathrm{O}+n e^{-}
$$

When the tip is placed at a large distance away from the substrate, a steady-state diffusion-limited current, $i_{\mathrm{T}, \infty}$, is established due to the hemispherical diffusion field as described previously. Under the negative feedback mode operation, when the soft UME approaches towards a non-active substrate (e.g., an insulator) within a few tip radii, the recorded current at the tip $\left(i_{\mathrm{T}}\right)$ decreases as the tip gets closer to the substrate, which is a consequence of the physical hindering of the diffusion of the redox mediator to the electrode surface by the substrate (Figure 2) producing a decrease of the recorded current $\left(i_{\mathrm{T}}<i_{\mathrm{T}, \infty}\right)$. This behavior is an outcome of the disturbance in hemispherical diffusion due to the physical hindering of the diffusion of the reduced species " $R$ " to the electrode surface.

(a)

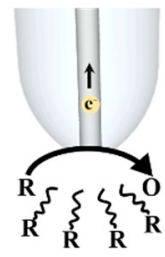

(c)

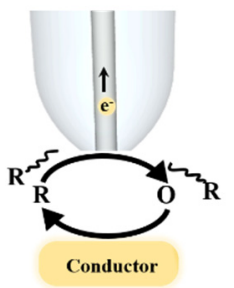

(e)

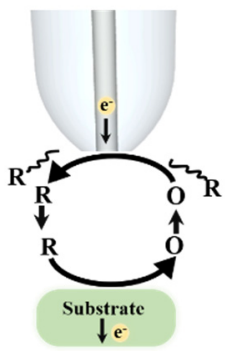

(b)

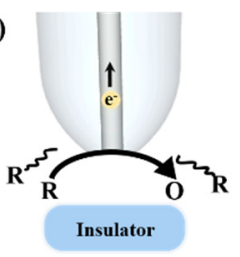

(d)

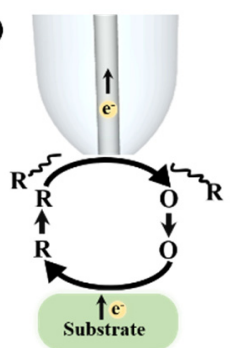

(f)

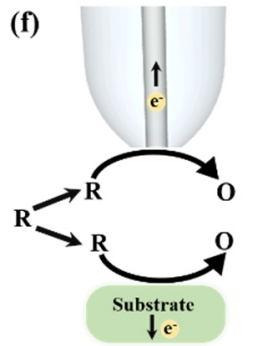

Figure 2. Schematic representation of SECM operation modes. (a) Steady-state diffusion in bulk solution; (b) Negative feedback mode; (c) Positive feedback mode; (d) Tip generation/substrate collection mode; (e) Substrate generation/tip collection mode; (f) Redox competition mode.

Conversely, in case of positive feedback (Figure 2), as the probe approaches a conductive or electrochemically active substrate, the surface of the substrate can immediately reduce the previously formed oxidized species " $\mathrm{O}$ " at the UME back to the reduced species " $\mathrm{R}$ ". Consequently, the recycling process leads to an increase of the tip current $\left(i_{\mathrm{T}}\right)$, which can become larger than the current in the bulk solution $\left(i_{\mathrm{T}}>i_{\mathrm{T}, \infty}\right)$.

In the generation/collection modes, the electrochemically active redox mediator is produced at either the probe electrode or the substrate electrode. If the generation of redox species results from the substrate electrode, and the tip collected the oxidized species " $\mathrm{O}$ " that diffuses away from the substrate, it is known as the substrate generation/tip collection $(\mathrm{SG} / \mathrm{TC})$ mode [11]. Here, the current recorded $\left(i_{\mathrm{T}}\right)$ will provide information about the 
electrochemical activity of the sample, and thus, reflects the concentration profile of the redox-active species near an active site of the sample [66]. Similarly, if the production of the redox mediator is at the UME probe surface, and then reacted electrochemically on the substrate, this is called tip generation/sample collection (TG/SC) mode (Figure 2). For this situation, the substrate currents provide the information of the local electrochemical reactivity at the tip location. The benefits of utilizing SG/TC or TG/SC modes are higher sensitivity due to the lesser background currents and the measurements at larger distances between the probe and the substrate can be achieved compared with feedback modes.

Figure 2 illustrates the working principle of redox competition (RC) mode, in which the tip and the substrate both compete for the same reactant $(\mathrm{R})$ because they undergo the same reaction. The closer the tip approaches to the sample surface, the more of the extensive consumption of the electrochemically active species, and thus, the tip current decreases. The advantage of $\mathrm{RC}$ mode is that the interference from the background current is relatively less as compared to the TG/SC mode. Therefore, the selection of the operation modes depends on many factors such as the source, concentration of analytes, background currents, and the electrochemical reactions occurring in the solution. All in all, the lateral resolution, current signal acquisition, and quality of the SECM image can be affected by numerous factors. The variables that need to be adjusted include the size of the sample area, the electron transfer rate, the concentration of the redox mediator, the tip-substrate distance, the size of the tip, and the scan rates of the probe. To achieve the best scanning conditions, slower scan rates and smaller step sizes or probes are preferred. However, these may lead to an extremely longer experiment time; for instance, $24 \mathrm{~h}$. Therefore, the simultaneous optimization of the resolution and the scanning time is a challenging task.

\section{The Study of Oxygen Reduction Reaction (ORR) by SECM}

In academia and industry, advanced electrochemical techniques and catalysts aimed for sustainable energy storage and conversion have attracted scientists' attention due to the escalated depletion of fossil fuels. In the next-generation energy devices, such as proton exchange membrane fuel cells (PEMFCs) and rechargeable metal-air batteries (MABs), $\mathrm{O}_{2}$ molecules are reduced at the cathode where the oxygen reduction reaction (ORR) takes place [67-69]. However, electrochemically breaking the $\mathrm{O}=\mathrm{O}$ bond is not easy because of the high bond energy. Therefore, the use of electrocatalysts for lowering the energy barrier of ORR reaction is an important issue. The $\mathrm{O}_{2}$ molecules can undergo the reduction either to form water directly through a four-electron transfer mechanism or by forming hydrogen peroxide as an intermediate through a two-electron transfer process [70,71].

For investigating the ORR by SECM, the generation/collection (TG/SC or SG/TC) mode and RC mode are often used for ORR investigation. In a typical case, the catalysts are modified on a sample electrode that generates $\mathrm{O}_{2}$ molecules and the tip collects them or vice versa. Thus, the recorded tip currents reveal the local activity of the electrocatalysts [72]. Schuhmann's group has studied the catalytic process of ORR that occurred on various catalyst candidates. They assessed the metal catalyst based on their ability to lead $\mathrm{O}_{2}$ reduction depending on the number of electrons transferred during the reaction time. The nature (e.g., selectivity) of a catalyst relies on whether a complete (four-electron reduction forming desired $\mathrm{H}_{2} \mathrm{O}$ ) or incomplete (two-electron reduction forming undesired $\mathrm{H}_{2} \mathrm{O}_{2}$ ) electron pathway was taken. To differentiate between two-electron and four-electron transfer, they prepared the sample at the Pt and the Au surface [44,73,74]. By applying different sample potentials and different operation modes of SECM, the ratio of reactions of the four-electron transfer process and two-electron transfer process can be investigated.

Noble metals, such as Pt, are often used in ORR catalysis [75]. However, the competing adsorption of the intermediates is the main reason why ORR at noble metals has a high overpotential. Therefore, synthesizing the novel alloy catalysts for lowering noble metal loading and increasing the catalytic efficiency is an important issue. SECM has been an ideal technique to compare the catalytic activity of nanoparticles composed of different elements [74]. 
In order to gain insights into the reactions occurring at the surface of these nanomaterials, the scanning electrochemical microscopy-atomic force microscopy (SECM-AFM) was used to map the catalytic currents with ultra-high resolution (around $50 \mathrm{~nm}$ ). Figure 3 demonstrates that the combination of SECM and AFM can reveal the Fe-coordinated nitrogen sites formed both in the edge as well as basal planes of highly ordered pyrolytic graphite (HOPG) and meanwhile, provides the topographical information on a nanometric scale. The Kolagatla group compared the HOPG surface with ammonia plasma-treated HOPG (N-HOPG), and iron and ammonia plasma-treated HOPG (Fe-N-HOPG) surfaces. They demonstrated that the edge planes of Fe-N-HOPG have enhanced catalytically active sites as compared to other tested surfaces, as the catalytic activity of the ORR in acidic solution arises mainly through the Fe coordinated ' $N$ ' sites, associated with structural defects in the HOPG surface [16]. This system enables a deeper understanding of the catalytic sites on different composites and thus, paves a way for a better design of the catalysts.

Topography
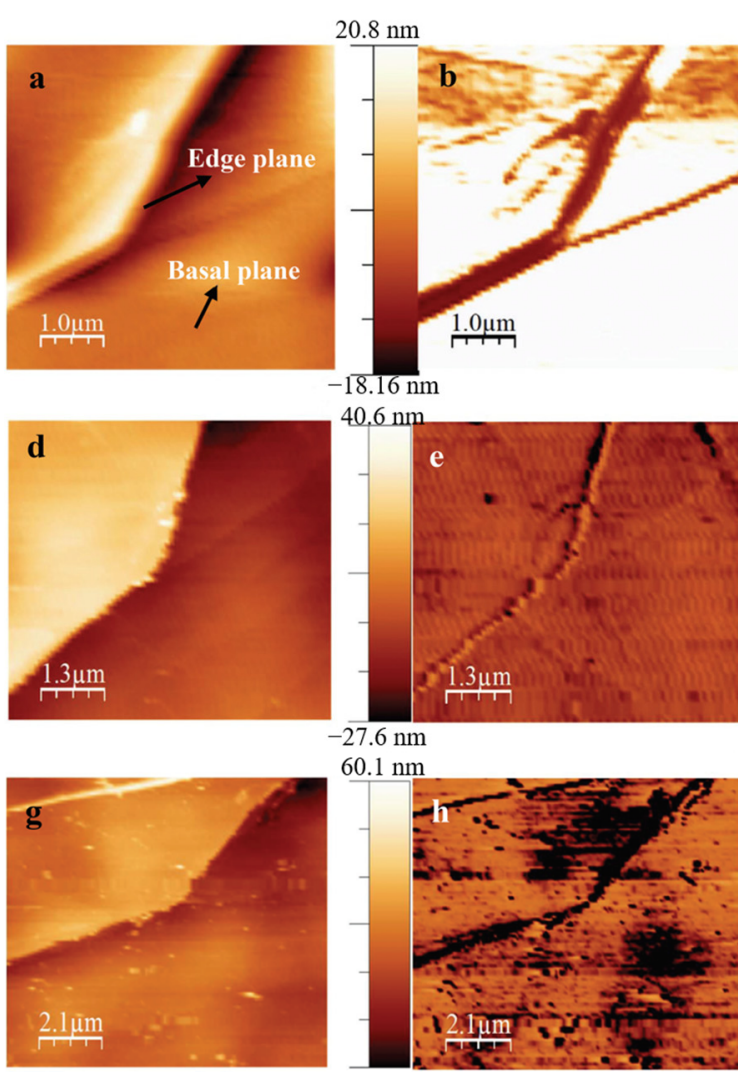

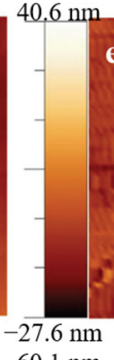

$60.1 \mathrm{~nm}$

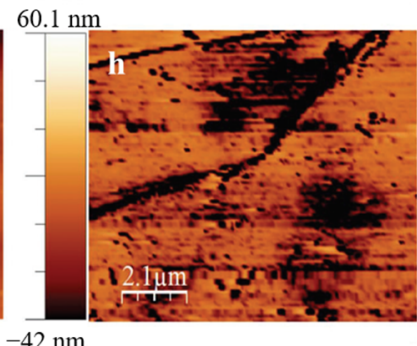

Peroxide oxidation current maps

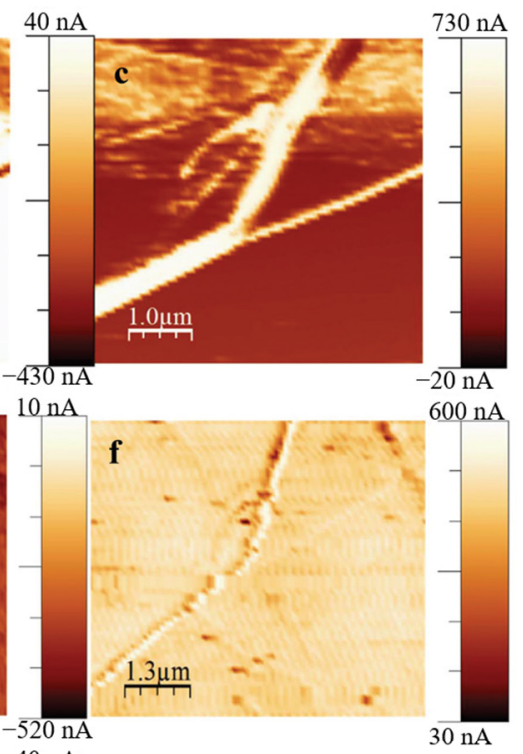
$40 \mathrm{nA}$ $720 \mathrm{nA}$

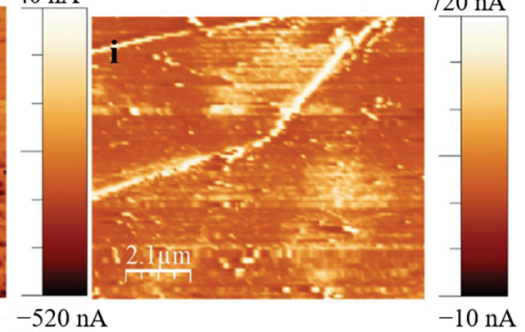

Figure 3. The AFM topography scan, oxygen reduction and peroxide oxidation current mapping images (in this order) of HOPG $(\mathbf{a}-\mathbf{c})$, N-HOPG $(\mathbf{d}-\mathbf{f})$, and Fe-N-HOPG (g-i), respectively. The applied substrate potentials for the oxygen reduction current mapping are $0.68 \mathrm{~V}$ (HOPG and N-HOPG) and $0.7 \mathrm{~V}$ (Fe-N-HOPG). The applied tip potential for the hydrogen peroxide oxidation current mapping is $1.2 \mathrm{~V}$. The SECM-AFM tip scan rate used for the current-mapping experiments is $15 \mathrm{~ms}$ per point; (1 ms per point $\left.=4 \mathrm{~nm} \mathrm{~ms}^{-1}\right)$. Reprinted from ref. [16]. Copyright 2009 , Royal Society of Chemistry; permission conveyed through Copyright Clearance Center, Inc.

In addition to AFM-SECM, other types of SECM related techniques, such as scanning electrochemical cell microscopy (SECCM) and SECM-SICM, were developed by Unwin and other researchers, for the visualization of individual catalytic sites. On the other hand, the modification of the tip structure is also a promising method for studying the chemical reactions in a specific environment such as in organic solvents. For instance, Wittstock 
and coworkers created a special UME composed of an opening of a micropipette (MP) containing the liquid-liquid interface near the Pt electrode. In this system, oxygen reduction and ion transfer across the liquid-liquid junction can be observed (Figure 4) [17]. The data showed that the strong catalytic activity of hydrated alkali metal ions on the formation rate of hydrogen peroxide. It varies systematically with the $\mathrm{pH}$ of the transferred alkali metal ions in the organic solvents. The catalytic activity was found to be increased as per the correlation of the hydration enthalpies of alkali metal ions $\left(\mathrm{K}^{+}<\mathrm{Na}^{+}<\mathrm{Li}^{+}\right)$. Hence, cations having higher hydration enthalpy offer higher driving force for ORR and, thereby, a higher rate for the generation of hydrogen peroxide. This strategy provides deeper insights into the optimization of biphasic fluidic systems containing aqueous and/or organic phases.

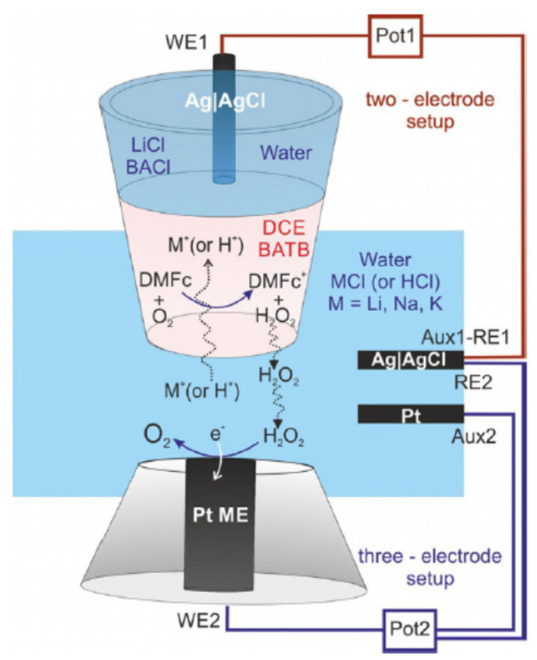

Figure 4. Schematic representation of a special UME composed of an opening of a micropipette (MP) containing the liquid-liquid interface near the Pt electrode being operated in SG/TC mode proposed by Wittstock and coworkers. Reprinted from ref. [17]. Copyright 2020, John Wiley and Sons (open access).

Apart from the artificially synthesized catalysts, enzymes composed of proteins can act as natural catalysts that carry out numerous biochemical reactions, including oxygen reduction. Therefore, Bard's group and other researchers also used SECM to characterize the catalytic reactivity of the enzymes, including multicopper oxidase bilirubin oxidase (BOD) or laccase spotted on the substrates [76].

\section{The Study of Oxygen Evolution Reaction (OER) by SECM}

The oxygen evolution reaction (OER) is the process of generating oxygen molecules through a chemical reaction. Oxygen molecules can be generated from the electrolysis of water, oxidation of water during oxygenic photosynthesis, or electrocatalytic oxygen evolution reactions $[12,19,41-43,45,49,77]$. In the fields related to metal-air batteries and solar fuel production or other renewable energy technologies, the catalysts for the OER reaction are usually composed of manganese oxides $(\mathrm{MnO})$, ruthenium, iridium oxides, and other first-row metals; however, they are costly and rare [77].

SECM can reveal the OER status in real-time and provide useful information on the reaction rate. In a recent study of OER, Bard's group used surface interrogation scanning electrochemical microscopy (SI-SECM) to investigate manganese oxidation state on the two electrodeposited manganese-based electrocatalysts, amorphous $\mathrm{MnO}_{\mathrm{x}}$, and perovskite $\mathrm{CaMnO}_{3}$. The workflow of the detection of the different manganese oxidation states on the two catalysts is presented in Figure 5. The intermediates of the OER process were generated by giving a voltage pulse on the substrate from the open circuit potential (OCP) to a certain potential for several seconds [19]. Consequently, the SECM probe enhanced the production of redox species that titrates adsorbed molecules on the substrate. During the OER process, 
$\mathrm{Mn}^{\mathrm{V}}$ species were identified in both electrocatalysts by analyzing the feedback currents and finally, the reaction rates calculated. Besides, the Bron group coupled Raman spectroscopy with SECM and demonstrated that in situ Raman-SECM can be utilized for mapping the OER activity of electrochemically deposited $\mathrm{Ni}$ and $\mathrm{Ni} / \mathrm{Fe}$ thin-film electrodes in an alkaline media. This in situ spectroelectrochemical methodology can provide clearer insights into the structure, structural changes, and resulting catalytic activity of NiFe oxides/hydroxides using Raman spectroscopy as well as simultaneously assess the onset of OER using SECM in SG/TC mode at the same location [42].

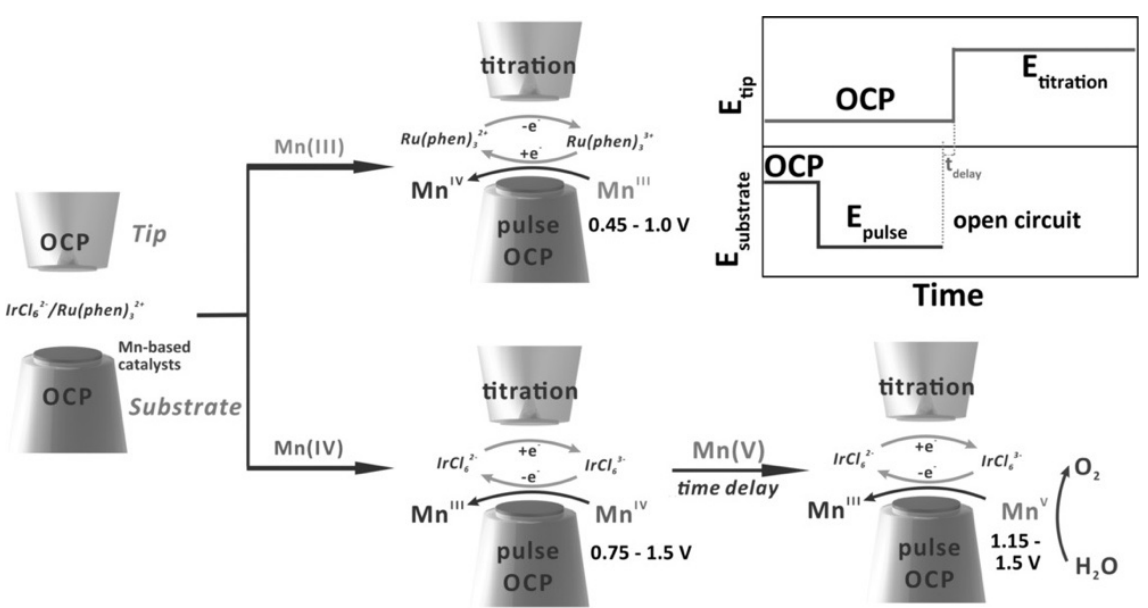

Figure 5. A systematic methodology for SI-SECM. The oxidation and reduction titrations were performed in two separate ways: one for $\mathrm{Mn}(\mathrm{III})$ using the redox titrant $\mathrm{Ru}(\mathrm{phen}) 3^{2+/ 3+}$, and another for $\mathrm{Mn}(\mathrm{IV})$ as well as $\mathrm{Mn}(\mathrm{V})$ using $\mathrm{IrCl}_{6}{ }^{2-/ 3-}$. Reprinted from ref. [19]. Copyright 2020, John Wiley and Sons

\section{The Study of Hydrogen Evolution Reaction (HER) by SECM}

Hydrogen is a promising alternative energy source that is more environmentally friendly and renewable. Therefore, the development of electrocatalysts for the hydrogen evolution reaction (HER) is an important concern. Typically, catalysts for HER reaction are composed of noble metals. In recent years, SECM has been used for screening earthabundant electrocatalysts, so the design of active non-precious metal-based catalysts can be improved.

Recently, single-atom catalysts (SACs) with the atomic distribution of metal active sites attracted great attention because of their extraordinary features of high reactivity. The characterization of SACs and the unveiling of catalytic mechanisms on individual sites can be done by the SECM [78]. However, the scanning of a single molecule or single nanoparticle catalysts is relatively feasible. Figure 6 presents that Mirkin's group revealed the HER reaction occurs on a single Au nanoparticle on a polyphenylene film. The current distribution in the SECM image under SG/TC mode reflects the catalytic site of the nanoparticle (Figure 7). 
a

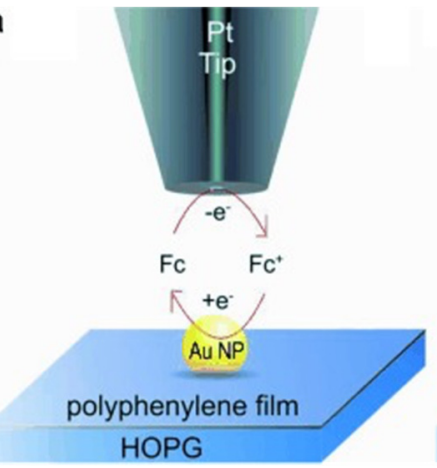

b

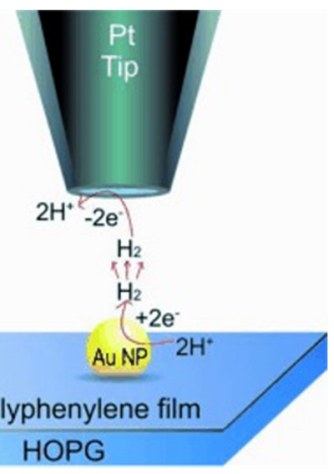

Figure 6. Illustration for SECM being operated on individual Au NPs via: (a) feedback (FB) mode, and (b) SG/TC mode. Reprinted from ref. [79]. Copyright 2014, John Wiley and Sons.

a

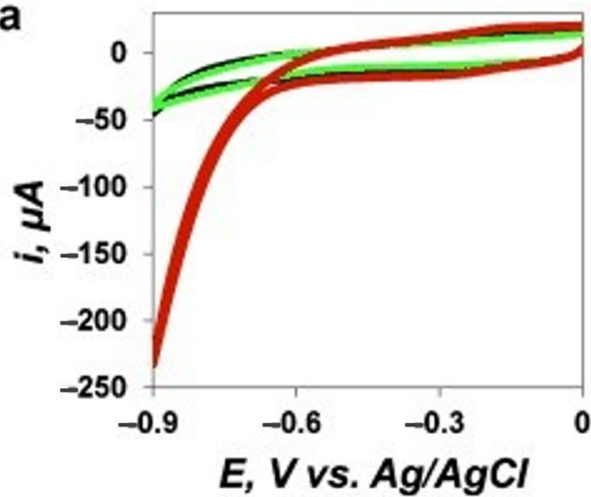

b

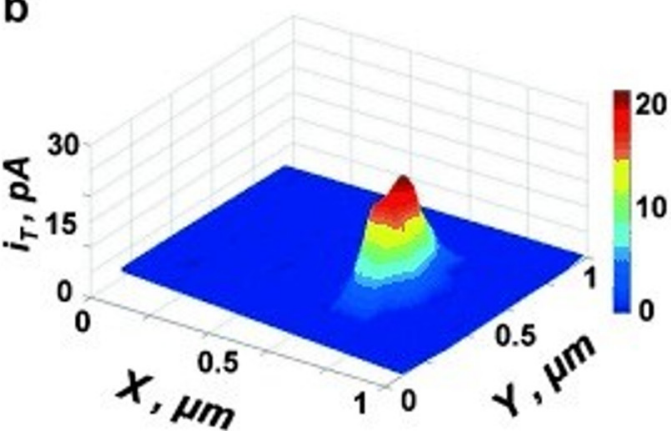

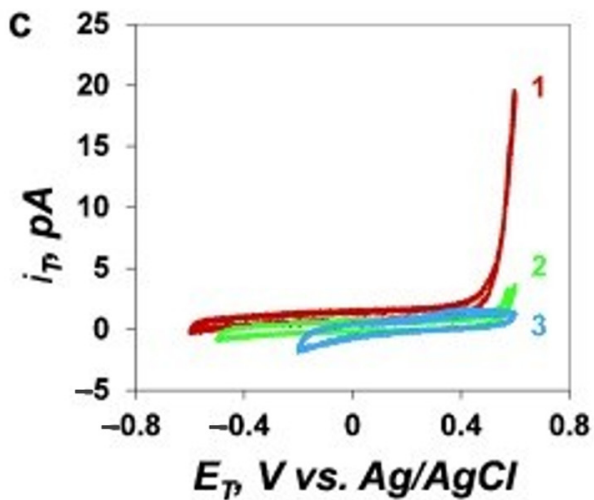

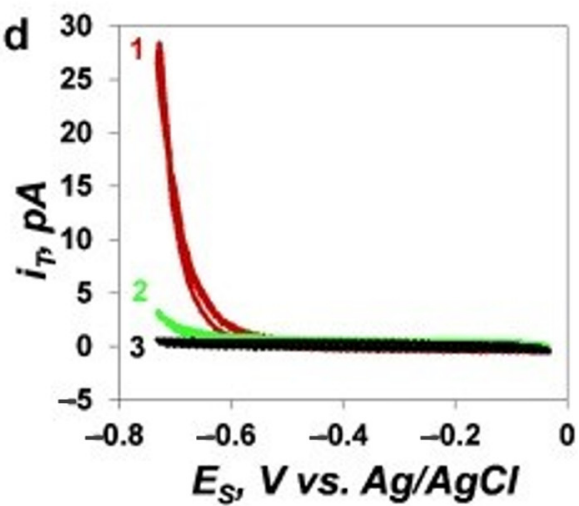

Figure 7. Voltammetric and SECM analysis for assessing the HER activity at gold nanoparticles (AuNPs). (a) Voltammograms corresponding to the reduction of protons at uncoated-HOPG (black), polyphenylene-coated HOPG (green), and 20-nm-gold nanoparticles (AuNPs) immobilized onto the modified HOPG (red). (b) SG/TC map corresponding to the HER activity at an individual 20-nm-gold nanoparticles acquired using a $15 \mathrm{~nm}$-radius Pt tip. $E_{\mathrm{T}}=500 \mathrm{mV}, E_{\mathrm{S}}=-750 \mathrm{mV}$ vs. $\mathrm{Ag} / \mathrm{AgCl}$. (c) Voltammograms obtained at a $60 \mathrm{~nm}$-radius Pt tip kept above the AuNP, $80 \mathrm{~nm}$ apart from the modified HOPG surface. $E_{\mathrm{T}}$ was scanned, and $E_{\mathrm{S}}$ (in $\mathrm{mV}$ ) was $-600(1),-500(2)$, and -100 (3). (d) Tip/substrate voltammograms were acquired at the same position as in (c). ES was scanned, and $E_{\mathrm{T}}$ (in $\mathrm{mV}$ ) was 500 (1), 400 (2), and 100 (3). The electrolyte solution comprised $10 \mathrm{mM} \mathrm{HClO}_{4}$ and $0.1 \mathrm{M} \mathrm{NaClO}_{4}$. The potential sweep rate was $100 \mathrm{mV} \mathrm{s}^{-1}$. Reprinted from ref. [79]. Copyright 2014, John Wiley and Sons.

Moreover, novel catalysts such as metal-organic frameworks (MOF) were explored, and the HER mechanism was also interpreted by SECM. The Hod group developed the electrochemically converted-MOFs (termed "EC-MOFs") into highly active electrocatalysts 
and optimized their conversion parameters (scan rate, potential range, and number of potential scans) for enhancing their electrochemical performance. They employed SECM in SG-TC mode to map in situ HER activity of the EC-MOF of ZIF-67 into patterned CoS $_{x}$, an HER electrocatalyst. Furthermore, they also performed in situ OER analysis of a bimetallic (Fe,Ni)-MIL-53 MOF into patterned $\mathrm{FeNiS}_{x}$, revealing that SECM can serve as a useful technique for optimization of localized catalyst fabrication as well as for designing MOF-based patterned arrays for electrochemical studies [15].

\section{The Emerging Applications of SECM}

In addition to the reactions mentioned above, other catalytic reactions including $\mathrm{CO}_{2}$ reduction, hydrogen peroxide production, and water oxidation, have been investigated by SECM. For instance, various methods for the elimination of greenhouse gases include energy-driven $\mathrm{CO}_{2}$ reduction, photothermal, thermal-catalytic, and artificial photosynthesis. Catalysts used for $\mathrm{CO}_{2}$ reduction reactions determine the efficiency of the conversion of $\mathrm{CO}_{2}$ toward high-value hydrocarbons $[23,26,27,80]$.

\section{Conclusions}

In this review, we summarized the recent progress of SECM screening of electrocatalysts for the reactions such as ORR, OER, and HER. The combination of SECM with other versatile techniques, such as AFM and SICM, allows the in-depth study of catalytic sites and obtaining useful information for catalyst design as well as improving their performance. Although there are numerous appealing features of applying different operation modes for studying electrocatalysts by SECM, there are still few challenges. For example, the speed of scanning cannot be accelerated too much because convection can interfere with the diffusion of reactants and products. On the other hand, the topography of the samples also limits the scanning area and probe types. In the future, efforts will be made to improve the design of a versatile SECM probe and hence, developing the optimized methodologies by combining SECM with other advanced SPM techniques to circumvent the upsurged global energy consumption.

Author Contributions: Conceptualization, T.-E.L.; writing-original draft preparation, T.-E.L. and A.P.; writing-review and editing, T.-E.L. and Anant Preet; supervision, T.-E.L.; project administration, T.-E.L.; funding acquisition, T.-E.L. All authors have read and agreed to the published version of the manuscript.

Funding: This research was funded by the Young Scholar Fellowship Program by the Ministry of Science and Technology in Taiwan, under Grant MOST 110-2636-E-009 -021.

Conflicts of Interest: The authors declare no conflict of interest.

\section{References}

1. Daviddi, E.; Shkirskiy, V.; Kirkman, P.M.; Robin, M.P.; Bentley, C.L.; Unwin, P.R. Nanoscale electrochemistry in a copper/aqueous/oil three-phase system: Surface structure-activity-corrosion potential relationships. Chem. Sci. 2021, 12, 3055-3069. [CrossRef]

2. Wang, S.; Yang, X.; Wu, F.; Min, L.; Chen, X.; Hou, X. Inner Surface Design of Functional Microchannels for Microscale Flow Control. Small 2019, 16, e1905318. [CrossRef] [PubMed]

3. Su, H.; Zhou, W.; Zhang, H.; Zhou, W.; Zhao, X.; Li, Y.; Liu, M.; Cheng, W.; Liu, Q. Dynamic Evolution of Solid-Liquid Electrochemical Interfaces over Single-Atom Active Sites. J. Am. Chem. Soc. 2020, 142, 12306-12313. [CrossRef] [PubMed]

4. Feng, J.; Huang, H.; Yan, S.; Luo, W.; Yu, T.; Li, Z.; Zou, Z. Non-oxide semiconductors for artificial photosynthesis: Progress on photoelectrochemical water splitting and carbon dioxide reduction. Nano Today 2020, 30, 100830. [CrossRef]

5. Suk, M.; Chung, M.W.; Han, M.H.; Oh, H.-S.; Choi, C.H. Selective $\mathrm{H}_{2} \mathrm{O}_{2}$ production on surface-oxidized metal-nitrogen-carbon electrocatalysts. Catal. Today 2021, 359, 99-105. [CrossRef]

6. Von Kurnatowski, M.; Bortz, M. Modeling and Multi-Criteria Optimization of a Process for $\mathrm{H}_{2} \mathrm{O}_{2}$ Electrosynthesis. Processes 2021, 9, 399. [CrossRef]

7. Ye, W.; Guo, X.; Ma, T. A review on electrochemical synthesized copper-based catalysts for electrochemical reduction of $\mathrm{CO}_{2}$ to C2+ products. Chem. Eng. J. 2021, 414, 128825. [CrossRef] 
8. Boutin, E.; Robert, M. Molecular Electrochemical Reduction of $\mathrm{CO}_{2}$ beyond Two Electrons. Trends Chem. $2021,3,359-372$. [CrossRef]

9. Sidhureddy, B.; Prins, S.; Wen, J.; Thiruppathi, A.R.; Govindhan, M.; Chen, A. Synthesis and Electrochemical Study of Mesoporous Nickel-Cobalt Oxides for Efficient Oxygen Reduction. ACS Appl. Mater. Interfaces 2019, 11, 18295-18304. [CrossRef]

10. Ramanavicius, S.; Ramanavicius, A. Charge Transfer and Biocompatibility Aspects in Conducting Polymer-Based Enzymatic Biosensors and Biofuel Cells. Nanomaterials 2021, 11, 371. [CrossRef]

11. Limani, N.; Boudet, A.; Blanchard, N.; Jousselme, B.; Cornut, R. Local probe investigation of electrocatalytic activity. Chem. Sci. 2021, 12, 71-98. [CrossRef]

12. Bertoncello, P. Advances on scanning electrochemical microscopy (SECM) for energy. Energy Environ. Sci. 2010, 3, 1620-1633. [CrossRef]

13. Kim, J.; Kim, B.-K.; Cho, S.K.; Bard, A.J. Tunneling Ultramicroelectrode: Nanoelectrodes and Nanoparticle Collisions. J. Am. Chem. Soc. 2014, 136, 8173-8176. [CrossRef] [PubMed]

14. Amatore, C.; Pebay, C.; Thouin, L.; Wang, A.; Warkocz, J.-S. Difference between Ultramicroelectrodes and Microelectrodes: Influence of Natural Convection. Anal. Chem. 2010, 82, 6933-6939. [CrossRef]

15. Liberman, I.; He, W.; Shimoni, R.; Ifraemov, R.; Hod, I. Spatially confined electrochemical conversion of metal-organic frameworks into metal-sulfides and their in situ electrocatalytic investigation via scanning electrochemical microscopy. Chem. Sci. 2019, 11, 180-185. [CrossRef]

16. Kolagatla, S.; Subramanian, P.; Schechter, A. Nanoscale mapping of catalytic hotspots on Fe, N-modified HOPG by scanning electrochemical microscopy-atomic force microscopy. Nanoscale 2018, 10, 6962-6970. [CrossRef]

17. Rastgar, S.; Santos, K.T.; Angelucci, C.A.; Wittstock, G. Catalytic Activity of Alkali Metal Cations for the Chemical Oxygen Reduction Reaction in a Biphasic Liquid System Probed by Scanning Electrochemical Microscopy. Chem. A Eur. J. 2020, 26, 10882-10890. [CrossRef]

18. Yu, Z. In-Situ and Real-Time Monitoring of Oxygen Evolution during Kolbe Reaction by Scanning Electrochemical Microscopy. Int. J. Electrochem. Sci. 2021, 16, 210240. [CrossRef]

19. Jin, Z.; Bard, A.J. Surface Interrogation of Electrodeposited MnOx and CaMnO3 Perovskites by Scanning Electrochemical Microscopy: Probing Active Sites and Kinetics for the Oxygen Evolution Reaction. Angew. Chem. Int. Ed. 2021, 60, 794-799. [CrossRef]

20. Kumar, S.; Sahoo, P.K.; Satpati, A.K. Electrochemical and SECM Investigation of MoS2/GO and MoS2/rGO Nanocomposite Materials for HER Electrocatalysis. ACS Omega 2017, 2, 7532-7545. [CrossRef]

21. Djire, A.; Wang, X.; Xiao, C.; Nwamba, O.C.; Mirkin, M.V.; Neale, N.R. Basal Plane Hydrogen Evolution Activity from Mixed Metal Nitride MXenes Measured by Scanning Electrochemical Microscopy. Adv. Funct. Mater. 2020, 30, 2001136. [CrossRef]

22. Iffelsberger, C.; $\mathrm{Ng}$, S.; Pumera, M. Catalyst coating of 3D printed structures via electrochemical deposition: Case of the transition metal chalcogenide MoSx for hydrogen evolution reaction. Appl. Mater. Today 2020, 20, 100654. [CrossRef]

23. Ahn, H.S.; Bard, A.J. Surface Interrogation of CoPi Water Oxidation Catalyst by Scanning Electrochemical Microscopy. J. Am. Chem. Soc. 2015, 137, 612-615. [CrossRef]

24. Soldà, A.; Valenti, G.; Marcaccio, M.; Giorgio, M.; Pelicci, P.G.; Paolucci, F.; Rapino, S. Glucose and Lactate Miniaturized Biosensors for SECM-Based High-Spatial Resolution Analysis: A Comparative Study. ACS Sensors 2017, 2, 1310-1318. [CrossRef]

25. Jayathilake, N.M.; Koley, D. Glucose Microsensor with Covalently Immobilized Glucose Oxidase for Probing Bacterial Glucose Uptake by Scanning Electrochemical Microscopy. Anal. Chem. 2020, 92, 3589-3597. [CrossRef] [PubMed]

26. Mayer, F.D.; Hosseini-Benhangi, P.; Sánchez-Sánchez, C.M.; Asselin, E.; Gyenge, E.L. Scanning electrochemical microscopy screening of $\mathrm{CO}_{2}$ electroreduction activities and product selectivities of catalyst arrays. Commun. Chem. 2020, 3, 1-9. [CrossRef]

27. Strange, L.E.; Yadav, J.; Li, X.; Pan, S. Editors' Choice-Review-Creating Electrocatalytic Heterojunctions for Efficient Photoelectrochemical $\mathrm{CO}_{2}$ Reduction to Chemical Fuels. J. Electrochem. Soc. 2020, 167, 146518. [CrossRef]

28. Wittstock, G.; Burchardt, M.; Pust, S.E.; Shen, Y.; Zhao, C. Scanning Electrochemical Microscopy for Direct Imaging of Reaction Rates. Angew. Chem. Int. Ed. 2007, 46, 1584-1617. [CrossRef]

29. Sun, X.; Li, W.; Mi, H.; Li, Y.; Zhang, P.; Ren, X. Nitrogen and sulfur co-doped graphene supported PdW alloys as highly active electrocatalysts for oxygen reduction reaction. Int. J. Hydrogen Energy 2018, 43, 5530-5540. [CrossRef]

30. Kim, S.-J.; Lee, S.-C.; Lee, C.; Kim, M.H.; Lee, Y. Evolution of silver to a better electrocatalyst: Water-assisted oxygen reduction reaction at silver chloride nanowires in alkaline solution. Nano Energy 2018, 48, 134-143. [CrossRef]

31. Singh, V.; Tiwari, A.; Nagaiah, T.C. Facet-controlled morphology of cobalt disulfide towards enhanced oxygen reduction reaction. J. Mater. Chem. A 2018, 6, 22545-22554. [CrossRef]

32. Tiwari, A.; Singh, V.; Nagaiah, T.C. Tuning the MnWO4 morphology and its electrocatalytic activity towards oxygen reduction reaction. J. Mater. Chem. A 2018, 6, 2681-2692. [CrossRef]

33. Michalak, M.; Roguska, A.; Nogala, W.; Opallo, M. Patterning Cu nanostructures tailored for $\mathrm{CO}_{2}$ reduction to electrooxidizable fuels and oxygen reduction in alkaline media. Nanoscale Adv. 2019, 1, 2645-2653. [CrossRef]

34. Zhang, Q.; Liu, P.; Zhu, Z.; Zhang, J.; Cao, F. The study of the $\mathrm{H}_{2} \mathrm{O}_{2}$ during oxygen reduction process on typically corroding metal surface using tip generation-substrate collection mode of SECM. Corros. Sci. 2020, 164, 108312. [CrossRef]

35. Tiwari, A.; Singh, V.; Mandal, D.; Nagaiah, T.C. Nitrogen containing carbon spheres as an efficient electrocatalyst for oxygen reduction: Microelectrochemical investigation and visualization. J. Mater. Chem. A 2017, 5, 20014-20023. [CrossRef] 
36. Xin, S.; Liu, Z.; Ma, L.; Sun, Y.; Xiao, C.; Li, F.; Du, Y. Visualization of the electrocatalytic activity of three-dimensional MoSe2@reduced graphene oxide hybrid nanostructures for oxygen reduction reaction. Nano Res. 2016, 9, 3795-3811. [CrossRef]

37. Dobrzeniecka, A.; Zeradjanin, A.R.; Masa, J.; Blicharska, M.; Wintrich, D.; Kulesza, P.J.; Schuhmann, W. Evaluation of kinetic constants on porous, non-noble catalyst layers for oxygen reduction-A comparative study between SECM and hydrodynamic methods. Catal. Today 2016, 262, 74-81. [CrossRef]

38. Ma, L.; Zhou, H.; Xin, S.; Xiao, C.; Li, F.; Ding, S. Characterization of local electrocatalytical activity of nanosheet-structured $\mathrm{ZnCO}_{2} \mathrm{O} 4 /$ carbon nanotubes composite for oxygen reduction reaction with scanning electrochemical microscopy. Electrochim. Acta 2015, 178, 767-777. [CrossRef]

39. Kolagatla, S.; Subramanian, P.; Schechter, A. Simultaneous Mapping of Oxygen Reduction Activity and Hydrogen Peroxide Generation on Electrocatalytic Surfaces. ChemSusChem 2019, 12, 2708-2714. [CrossRef]

40. O'Connell, M.A.; Lewis, J.R.; Wain, A.J. Electrochemical imaging of hydrogen peroxide generation at individual gold nanoparticles. Chem. Commun. 2015, 51, 10314-10317. [CrossRef]

41. Konkena, B.; Masa, J.; Botz, A.J.R.; Sinev, I.; Xia, W.; Koßmann, J.; Drautz, R.; Muhler, M.; Schuhmann, W. Metallic NiPS3@NiOOH Core-Shell Heterostructures as Highly Efficient and Stable Electrocatalyst for the Oxygen Evolution Reaction. ACS Catal. 2017, 7, 229-237. [CrossRef]

42. Steimecke, M.; Seiffarth, G.; Bron, M. In Situ Characterization of Ni and Ni/Fe Thin Film Electrodes for Oxygen Evolution in Alkaline Media by a Raman-Coupled Scanning Electrochemical Microscope Setup. Anal. Chem. 2017, 89, 10679-10686. [CrossRef] [PubMed]

43. Chakrabarty, S.; Mukherjee, A.; Su, W.-N.; Basu, S. Improved bi-functional ORR and OER catalytic activity of reduced graphene oxide supported $\mathrm{ZnCO}_{2} \mathrm{O} 4$ microsphere. Int. J. Hydrogen Energy 2019, 44, 1565-1578. [CrossRef]

44. Barwe, S.; Andronescu, C.; Engels, R.; Conzuelo, F.; Seisel, S.; Wilde, P.; Chen, Y.-T.; Masa, J.; Schuhmann, W. Cobalt metalloid and polybenzoxazine derived composites for bifunctional oxygen electrocatalysis. Electrochim. Acta 2019, 297, 1042-1051. [CrossRef]

45. Tavakkoli, M.; Flahaut, E.; Peljo, P.; Sainio, J.; Davodi, F.; Lobiak, E.V.; Mustonen, K.; Kauppinen, E.I. Mesoporous Single-AtomDoped Graphene-Carbon Nanotube Hybrid: Synthesis and Tunable Electrocatalytic Activity for Oxygen Evolution and Reduction Reactions. ACS Catal. 2020, 10, 4647-4658. [CrossRef]

46. Jasion, D.; Barforoush, J.M.; Qiao, Q.; Zhu, Y.; Ren, S.; Leonard, K.C. Low-Dimensional Hyperthin FeS2 Nanostructures for Efficient and Stable Hydrogen Evolution Electrocatalysis. ACS Catal. 2015, 5, 6653-6657. [CrossRef]

47. Xiaolin, Z.; Du, M.; Mleczko, M.J.; Koh, A.L.; Nishi, Y.; Pop, E.; Bard, A.J.; Zheng, X. Kinetic Study of Hydrogen Evolution Reaction over Strained MoS2 with Sulfur Vacancies Using Scanning Electrochemical Microscopy. J. Am. Chem. Soc. 2016, 138, 5123-5129. [CrossRef]

48. Sun, T.; Zhang, H.; Wang, X.; Liu, J.; Xiao, C.; Nanayakkara, S.U.; Blackburn, J.L.; Mirkin, M.V.; Miller, E.M. Nanoscale mapping of hydrogen evolution on metallic and semiconducting MoS2 nanosheets. Nanoscale Horiz. 2018, 4, 619-624. [CrossRef]

49. Gao, X.; Chen, Y.; Sun, T.; Huang, J.; Zhang, W.; Wang, Q.; Cao, R. Karst landform-featured monolithic electrode for water electrolysis in neutral media. Energy Environ. Sci. 2020, 13, 174-182. [CrossRef]

50. Jedraszko, J.; Adamiak, W.; Nogala, W.; Girault, H.H.; Opallo, M. SECM study of hydrogen photogeneration in a 1,2dichloroethane I water biphasic system with decamethylruthenocene electron donor regeneration. J. Electroanal. Chem. 2018, 819, 101-106. [CrossRef]

51. Arrocha-Arcos, A.; Cervantes-Alcalá, R.; Huerta-Miranda, G.; Miranda-Hernández, M. Electrochemical reduction of Bicarbonate to Formate with Silver Nanoparticles and Silver Nanoclusters supported on Multiwalled Carbon Nanotubes. Electrochim. Acta 2017, 246, 1082-1087. [CrossRef]

52. Kai, T.; Zhou, M.; Duan, Z.; Henkelman, G.A.; Bard, A.J. Detection of $\mathrm{CO}_{2} \bullet-$ in the Electrochemical Reduction of Carbon Dioxide in N,N-Dimethylformamide by Scanning Electrochemical Microscopy. J. Am. Chem. Soc. 2017, 139, 18552-18557. [CrossRef] [PubMed]

53. Lin, Y.-T.; Darvishi, S.; Preet, A.; Huang, T.-Y.; Lin, S.-H.; Girault, H.H.; Wang, L.; Lin, T.-E. A Review: Electrochemical Biosensors for Oral Cancer. Chemosensors 2020, 8, 54. [CrossRef]

54. Lin, T.-E.; Rapino, S.; Girault, H.H.; Lesch, A. Electrochemical imaging of cells and tissues. Chem. Sci. 2018, 9, 4546-4554. [CrossRef] [PubMed]

55. Polcari, D.; Dauphin-Ducharme, P.; Mauzeroll, J. Scanning Electrochemical Microscopy: A Comprehensive Review of Experimental Parameters from 1989 to 2015. Chem. Rev. 2016, 116, 13234-13278. [CrossRef]

56. Izquierdo, J.; Knittel, P.; Kranz, C. Scanning electrochemical microscopy: An analytical perspective. Anal. Bioanal. Chem. 2017, 410, 307-324. [CrossRef]

57. Lin, T.-E.; Lesch, A.; Li, C.-L.; Girault, H.H. Mapping the antioxidant activity of apple peels with soft probe scanning electrochemical microscopy. J. Electroanal. Chem. 2017, 786, 120-128. [CrossRef]

58. Bondarenko, A.; Lin, T.-E.; Stupar, P.; Lesch, A.; Cortés-Salazar, F.; Girault, H.H.; Pick, H.M. Fixation and Permeabilization Approaches for Scanning Electrochemical Microscopy of Living Cells. Anal. Chem. 2016, 88, 11436-11443. [CrossRef] [PubMed]

59. Lin, T.-E.; Cortés-Salazar, F.; Lesch, A.; Qiao, L.; Bondarenko, A.; Girault, H.H. Multiple scanning electrochemical microscopy mapping of tyrosinase in micro-contact printed fruit samples on polyvinylidene fluoride membrane. Electrochim. Acta 2015, 179, 57-64. [CrossRef] 
60. Darvishi, S.; Pick, H.M.; Lin, T.-E.; Zhu, Y.; Li, X.; Ho, P.-C.; Girault, H.H.; Lesch, A. Tape-Stripping Electrochemical Detection of Melanoma. Anal. Chem. 2019, 91, 12900-12908. [CrossRef]

61. Salomo, M.; Pust, S.E.; Wittstock, G.; Oesterschulze, E. Integrated cantilever probes for SECM/AFM characterization of surfaces. Microelectron. Eng. 2010, 87, 1537-1539. [CrossRef]

62. Chen, C.C.; Zhou, Y.; Baker, L.A. Scanning ion conductance microscopy. Ann. Rev. Anal. Chem. 2012, 5, 207-228. [CrossRef] [PubMed]

63. Takahashi, Y.; Kumatani, A.; Shiku, H.; Matsue, T. Scanning Probe Microscopy for Nanoscale Electrochemical Imaging. Anal. Chem. 2016, 89, 342-357. [CrossRef] [PubMed]

64. Lin, T.-E.; Bondarenko, A.; Lesch, A.; Pick, H.; Cortés-Salazar, F.; Girault, H.H. Monitoring Tyrosinase Expression in Nonmetastatic and Metastatic Melanoma Tissues by Scanning Electrochemical Microscopy. Angew. Chem. Int. Ed. 2016, 55, 3813-3816. [CrossRef] [PubMed]

65. Lin, T.-E.; Lu, Y.-J.; Sun, C.-L.; Pick, H.; Chen, J.-P.; Lesch, A.; Girault, H.H. Soft Electrochemical Probes for Mapping the Distribution of Biomarkers and Injected Nanomaterials in Animal and Human Tissues. Angew. Chem. Int. Ed. 2017, 56, 16498-16502. [CrossRef] [PubMed]

66. Huang, L.; Li, Z.; Lou, Y.; Cao, F.; Zhang, D.; Li, X. Recent Advances in Scanning Electrochemical Microscopy for Biological Applications. Materials 2018, 11, 1389. [CrossRef]

67. Wang, L.; Chen, M.; Küngas, R.; Lin, T.-E.; Diethelm, S.; Maréchal, F.; Van Herle, J. Power-to-fuels via solid-oxide electrolyzer: Operating window and techno-economics. Renew. Sustain. Energy Rev. 2019, 110, 174-187. [CrossRef]

68. Ma, S.; Lin, M.; Lin, T.-E.; Lan, T.; Liao, X.; Maréchal, F.; Van Herle, J.; Yang, Y.; Dong, C.; Wang, L. Fuel cell-battery hybrid systems for mobility and off-grid applications: A review. Renew. Sustain. Energy Rev. 2021, 135, 110119. [CrossRef]

69. Wang, L.; Zhang, Y.; Pérez-Fortes, M.; Aubin, P.; Lin, T.-E.; Yang, Y.; Maréchal, F.; Van Herle, J. Reversible solid-oxide cell stack based power-to-X-to-power systems: Comparison of thermodynamic performance. Appl. Energy 2020, 275, 115330. [CrossRef]

70. Wang, X.; Li, Z.; Qu, Y.; Yuan, T.; Wang, W.; Wu, Y.; Li, Y. Review of Metal Catalysts for Oxygen Reduction Reaction: From Nanoscale Engineering to Atomic Design. Chem 2019, 5, 1486-1511. [CrossRef]

71. Ma, R.; Lin, G.; Zhou, Y.; Liu, Q.; Zhang, T.; Shan, G.; Yang, M.; Wang, J. A review of oxygen reduction mechanisms for metal-free carbon-based electrocatalysts. NPJ Comput. Mater. 2019, 5, 78. [CrossRef]

72. Fernández, J.L.; Walsh, D.A.; Bard, A.J. Thermodynamic Guidelines for the Design of Bimetallic Catalysts for Oxygen Electroreduction and Rapid Screening by Scanning Electrochemical Microscopy. M-Co (M: Pd, Ag, Au). J. Am. Chem. Soc. 2005, 127, 357-365. [CrossRef] [PubMed]

73. Eckhard, K.; Schuhmann, W. Localised visualisation of $\mathrm{O} 2$ consumption and $\mathrm{H}_{2} \mathrm{O}_{2}$ formation by means of SECM for the characterisation of fuel cell catalyst activity. Electrochim. Acta 2007, 53, 1164-1169. [CrossRef]

74. Nagaiah, T.C.; Maljusch, A.; Chen, X.; Bron, M.; Schuhmann, W. Visualization of the Local Catalytic Activity of Electrodeposited Pt-Ag Catalysts for Oxygen Reduction by means of SECM. ChemPhysChem 2009, 10, 2711-2718. [CrossRef] [PubMed]

75. Liu, M.; Zhao, Z.; Duan, X.; Huang, Y. Nanoscale Structure Design for High-Performance Pt-Based ORR Catalysts. Adv. Mater. 2019, 31, e1802234. [CrossRef] [PubMed]

76. Fernández, J.L.; Mano, N.; Heller, A.; Bard, A.J. Optimization Of “Wired” Enzyme O2-Electroreduction Catalyst Compositions by Scanning Electrochemical Microscopy. Angew. Chem. Int. Ed. 2004, 43, 6355-6357. [CrossRef] [PubMed]

77. Bergmann, A.; Zaharieva, I.; Dau, H.; Strasser, P. Electrochemical water splitting by layered and 3D cross-linked manganese oxides: Correlating structural motifs and catalytic activity. Energy Environ. Sci. 2013, 6, 2745-2755. [CrossRef]

78. Li, P.; Jin, Z.; Qian, Y.; Fang, Z.; Xiao, D.; Yu, G. Supramolecular confinement of single Cu atoms in hydrogel frameworks for oxygen reduction electrocatalysis with high atom utilization. Mater. Today 2020, 35, 78-86. [CrossRef]

79. Sun, T.; Yu, Y.; Zacher, B.J.; Mirkin, M.V. Scanning Electrochemical Microscopy of Individual Catalytic Nanoparticles. Angew. Chem. Int. Ed. 2014, 53, 14120-14123. [CrossRef] [PubMed]

80. Kromer, M.L.; Simpson, B.H.; Rodríguez-López, J. Evaluating the impact of catalyst selection and semiconductor band edge on the photoelectrochemical production of $\mathrm{H}_{2} \mathrm{O}_{2}$ via a real-time in situ probe. J. Electroanal. Chem. 2020, 875, 114677. [CrossRef] 